\title{
Evidence for a Regime Shift in Nitrogen Export from a Forested Watershed
}

\author{
J. R. Webster, ${ }^{1 *}$ J. D. Knoepp, ${ }^{2}$ W. T. Swank, ${ }^{2}$ and C. F. Miniat ${ }^{2}$
}

${ }^{1}$ Department of Biological Sciences, Virginia Polytechnic Institute and State University, 1405 Perry St., 1016 Derring Hall (MC 0406), Blacksburg, Virginia 24061, USA; ${ }^{2}$ Coweeta Hydrologic Laboratory, Center for Forest Watershed Research, Southern Research Station, USDA Forest Service, Otto, North Carolina 28763, USA

\begin{abstract}
In this study, we document a functional regime shift in stream inorganic nitrogen $(\mathrm{N})$ processing indicated by a major change in $\mathrm{N}$ export from a forested watershed. Evidence from 36 years of data following experimental clearcut logging at Coweeta Hydrologic Laboratory, NC, suggests that forest disturbance in this area can cause elevation of dissolved inorganic $\mathrm{N}$ (DIN) loss lasting decades or perhaps longer. This elevation of $\mathrm{N}$ export was apparently caused by an initial pulse of organic matter input, reduced vegetation uptake, increased mineralization of soil organic $\mathrm{N}$, and $\mathrm{N}$ fixation by black locust-associated bacteria following clearcut logging. In forested reference watersheds at Coweeta, maximum DIN concentration occurs in summer when base flow is low, but the clearcut
\end{abstract}

\section{INTRODUCTION}

Ecosystem regime shift has been defined as a major change to a new and fundamentally different state

Received 11 December 2015; accepted 5 February 2016; published online 11 April 2016

The data used in this paper are available at the Coweeta LTER website, www.coweeta.uga.edu.

Author Contributions JRW and WTS contributed to writing the original proposal funding the WS 7 study. All co-authors contributed to writing proposals that funded subsequent data collection and analysis. WTS, JDK, and CFM supervised much of the data collection. JRW did most of the data analysis, and all co-authors contributed to writing the manuscript.

*Corresponding author; e-mail: jwebster@vt.edu watershed shifted to a pattern of maximum winter DIN concentration. The seasonal pattern of DIN concentration and export from reference watersheds can be explained by terrestrial and in-stream processes, but following clearcutting, elevated DIN availability saturated both terrestrial and in-stream uptake, and the $\mathrm{N}$ export regime became dominated by hydrologic transport. We suggest that the long-term elevation of stream DIN concentration and export along with the changes in seasonality of DIN export and the relationship between concentration and discharge represent a functional regime shift initiated by forest disturbance.

Key words: watershed; nitrogen; budget; regime shift; clearcutting; stream. 
deposition in forests in the central Appalachians, $\mathrm{N}$ export from these forests began to decline (Eshleman and others 2013). Similar rapid recovery has been shown in experimental studies of reduction of $\mathrm{N}$ deposition (Bredemeier and others 1995; Corre and Lamersdorf 2004). Also, many studies have shown elevated $\mathrm{N}$ export from watersheds following forest cutting (for example, Likens and others 1970), but recovery to near pre-disturbance $\mathrm{N}$ export is usually rapid (Bormann and Likens 1979b). In this second example, the major feedback mechanism responsible for $\mathrm{N}$ export recovery is rapid vegetation regrowth and uptake of inorganic N (Gholz and others 1985; Martin and others 2000; Hornbeck and others 2014).

Ecosystems are not globally stable, and extreme disturbances may cause an ecosystem to move outside its domain of stability to an alternative state (Lewontin 1969; Holling 1973; May 1977; Gunderson 2000). Examples include deposition of toxic chemicals for copper smelting at Copper Hill, Tennessee (Johnson 2002) and massive erosion due to cotton farming in southeast United States (Richter and Markewitz 2001). In these examples, the biological feedback mechanisms for recovery no longer exist, preventing recovery to the original ecosystem. However, recovery toward a more functional ecosystem may occur through extensive management intervention such as the planting of nearly 20 million trees and shrubs at Copper Hill (Johnson 2002). These permanent changes in ecosystems have been referred to as changes in the domain of stability, critical transitions, tipping points, ecological thresholds, or regime shifts (for example, Holling 1973; Woodwell 1975; Gunderson 2000; Groffman and others 2006; Patten 2014).

Ecosystem regime shifts have been well documented in lakes (Scheffer and others 1997; Carpenter and others 1999), streams (Dent and others 2002; Robinson and Uehlinger 2008), and oceans (Collie and others 2004) and suggested for a variety of other ecosystems including coral reefs, woodlands, and deserts (Scheffer and others 2001). In most of these examples, the regime shift was identified by changes in the biotic assemblage. In this study, we document a functional regime shift indicated by change in $\mathrm{N}$ export from a forested watershed, which occurred in response to clearcut logging.

Undisturbed forest watersheds are highly $\mathrm{N}$ retentive (for example, Thompson and others 2011 ), and $\mathrm{N}$ export is largely biologically controlled. However, accumulation of available $\mathrm{N}$ beyond what can be biologically immobilized results in $\mathrm{N}$ saturation (Aber and others 1989), and $\mathrm{N}$ export can move toward hydrologic control where $\mathrm{N}$ export is closely related to hydrologic export. The excess $\mathrm{N}$ inputs may result from atmospheric deposition (for example, Dise and Wright 1995), fertilization (Peterjohn and others 1996), defoliation (for example, Swank and others 1981; Riscassi and Scanlon 2009), other disturbances that increase $\mathrm{N}$ mineralization (Bormann and Likens 1979a), or often a combination of processes (Aber and others 2002). Elevated export of dissolved inorganic $\mathrm{N}$ (DIN = nitrate + ammonium) is a common watershed-scale response to these disturbances (for example, Likens and others 1970; Aber and others 1989). Yet, forested ecosystems are highly resilient, and, as noted above, DIN export has usually been observed to recover rapidly as the vegetation regrows.

The inference that DIN export is biologically controlled arises from studies quantifying the magnitude of export and how it changes following vegetation manipulation and also from observational studies noting significant seasonality in stream nutrient concentrations. Changes in the $\mathrm{N}$ cycle caused by forest logging have been known for over 100 years (Vitousek and Melillo 1979). Experimental clearfelling followed by inhibition of vegetation regrowth (Watershed 2) at Hubbard Brook Experimental Forest (NH) resulted in very high concentration of nitrate (up to $18 \mathrm{mg} \mathrm{N} \mathrm{L}^{-1}$ ) in the stream draining this watershed (Likens and others 1970). Nitrogen losses from this experiment were extreme, and most other studies have shown significant but much smaller losses (for example, Auberton and Patric 1974; Vitousek and Melillo 1979; Martin and others 1984; Van Miegroet and others 1992; Adams and Kochendenfer 2014). In some studies, researchers saw no increase in $\mathrm{N}$ export or the increased export could be attributed entirely to an increase in discharge (Ranger and others 2007; Marchman and others 2013). Rhoades and others (2013) saw no increase in $\mathrm{N}$ export in response to heavy lodgepole pine mortality caused by western pine beetle infestation, which they attributed to compensatory growth of residual vegetation. Where elevated $\mathrm{N}$ export was observed, recovery to more normal $\mathrm{N}$ loss was rapid, reinforcing the conclusion that DIN export is biologically controlled.

Observational studies across many ecosystems have noted significant seasonality in stream nutrient concentrations that corresponds directly to the seasonality of biological processes. For example, Vitousek and Reiners (1975) observed peak nitrate concentration in winter and minimum in summer in the White Mountains of New Hampshire, which 
they attributed to dormant or active terrestrial vegetation. Goodale and others (2009) described the winter peak in nitrate concentrations as the conventional seasonal pattern for forested watersheds with snow-dominated hydrology throughout much of the U.S. and Europe. These late winter peaks may be the result of flushing of winter-accumulated nitrate during spring snowmelt (for example, Creed and others 1996) and are followed by spring and early summer declines in nitrate concentrations that have been attributed, at least in some streams, to uptake by periphyton (Webb and Walling 1985; Walling and Webb 1986; Svendsen and others 1995; Mulholland and Hill 1997, Sabater and others 2000; Bernhardt and others 2003, 2005). Many watersheds, particularly those that are not dominated by snow hydrology, do not fit this pattern but rather are characterized by peak stream nitrate concentrations in the summer. For example, summer maximum nitrate concentrations have been observed in Japan (Mitchell and others 1997; Ohte and others 2001; Ohte 2012), Baltimore, MD (Tague and Band 2004), the Upper Susquehanna River basin in New York (Goodale and others 2009), eastern Tennessee (Lutz and others 2012), and western North Carolina at Coweeta Hydrologic Laboratory (Swank and Vose 1997; Worrall and others 2003). This summer peak has generally been attributed to high soil microbial nitrification under conditions of adequate soil water availability and warm soil temperatures during the growing season (Knoepp and Swank 1998; Goodale and others 2009; Brookshire and others 2011; Ohte 2012). Band and others (2001) suggested that this accumulated nitrate could then be flushed from riparian zones during summer, a time when there is also little overland flow to dilute streamwater concentrations.

Streams with either winter or summer peak nitrate concentration often have a decline in concentration after autumn leaf abscission, attributable to in-stream uptake of $\mathrm{N}$ by leaf-decomposing fungi and bacteria (for example, Mulholland and Hill 1997; Burns 1998; Goodale and others 2009; Bernal and others 2012; Sebestyen and others 2014) as this is a time of maximum heterotrophic production and $\mathrm{N}$ immobilization in forest-covered streams (for example, Roberts and Mulholland 2007; Roberts and others 2007; Valett and others 2008). Modeling studies have also suggested that in-stream biotic uptake and subsequent mineralization can significantly modify $\mathrm{N}$ concentrations in forested watershed streams (Webster and others 2009; Webster and others 2016). However, elevated $\mathrm{N}$ inputs to streams following dis- turbance may exceed the uptake capacity of instream processes helping to cause a shift in the magnitude and seasonal timing of watershed $\mathrm{N}$ export (Lin and others 2015).

The significance of biological processes in watershed $\mathrm{N}$ dynamics is illustrated by the role of terrestrial vegetation in determining the magnitude of $\mathrm{N}$ export and the importance of both terrestrial and stream processes in determining the seasonality of $\mathrm{N}$ export. When this biological control is disrupted, export may be controlled more by the hydrologic flux of water through a watershed (transport limited) rather than by the availability of $\mathrm{N}$ resulting from the net production by biological and geochemical processes (source limited) (Ocampo and others 2006; Basu and others 2010).

The relationship between stream chemical concentration $(C)$ and discharge $(Q)$ is often expressed as a power function

$$
C=a Q^{b}
$$

where $a$ and $b$ are fitted constants. For many streams, concentration of most chemicals decreases with discharge (that is, $b$ is negative; Walling and Webb 1986) indicating source limitation and biological or biogeochemical regulation of the chemical. The exponent may also be approximately zero if there is chemostasis. This may occur for weathering-derived chemicals or when there is a large storage of the chemical within the watershed (Godsey and others 2009; Thompson and others 2011). In some cases, chemical concentration may increase with discharge, that is, $b$ may be positive. This suggests that during storms or snowmelt, water is traveling along flowpaths where it encounters high levels of the chemical. This is described as flushing (Hornberger and others 1994; Creed and others 1996) and occurs in undisturbed forest $\mathrm{N}$ cycles during snowmelt where there is significant snowpack accumulation and a build-up of available soil N (Stoddard 1994). In watersheds without snowpack, when $b$ is positive and $\mathrm{N}$ concentration increases with discharge, this relationship could indicate excess $\mathrm{N}$ input into the watershed and a shift toward hydrologic control of $\mathrm{N}$ export.

The original objective of the experimental clearcutting study was to examine the stability of a forested watershed following disturbance (Swank and Webster 2014a). In the original 1974 proposal to fund the research, it was predicted that the forest would exhibit rapid recovery (Monk and others 1977; Webster and others 2014b). However, 20 years after the experimental clearcutting, it became evident that the $\mathrm{N}$ dynamics of this watershed were not exhibiting the expected rapid recovery 
(Swank and Vose 1997). In the current study, we use long-term stream DIN data to test the prediction of rapid recovery. We present evidence that the stream $\mathrm{N}$ export response represents a functional regime shift mediated by a change from biological to hydrologic control of $\mathrm{N}$ export. We examine data for three lines of evidence supporting the conclusion of a regime shift: (1) long-term increase in the magnitude of DIN concentration and export compared to reference watersheds; (2) shift in the peak of DIN concentration and export from summer to winter; and (3) change in the relationship between discharge and concentration from source limited to transport limited. We use data from a 42-year study of Watershed 7 (WS 7) at Coweeta Hydrologic Laboratory. This time period includes 4 years before clearcutting, 2 years when roads were being built on the watershed and logging was actually taking place, and 36 years after cutting. WS 7 has been extensively studied (Swank and Webster 2014a) and patterns of annual N export were reported by Adams and others (2014) and Swank and others (2014). Here, we extend these analyses to include seasonal and hydrologic dynamics of $\mathrm{N}$ chemistry in comparison to a reference watershed.

\section{MeTHODS}

\section{Site Description}

Coweeta Hydrologic Laboratory is located in the southern Appalachian Mountains of southwestern North Carolina (Swank and Webster 2014b). Elevation ranges from 679 to $1592 \mathrm{~m}$. Mean annual precipitation is about $200 \mathrm{~cm}$ and mean annual temperature is $12.6^{\circ} \mathrm{C}$. Precipitation at Coweeta does not show much seasonal variation but is slightly higher in winter and lower in late summer to early fall (Swift and others 1988). Parent materials are metamorphosed granitic schist and gneiss. Dominant hillslope soils are mesic Typic Dystrochrepts or Hapludults. Riparian and high elevation soils are mesic Typic Haplumbrepts. Soil depths average $1 \mathrm{~m}$ and are underlain by a saprolite layer up to $5 \mathrm{~m}$ deep. Watershed 2 (WS 2) is a 12.3-ha reference watershed adjacent to WS 7 and drained by Shope Branch. It has an altitude range from 709 to $1004 \mathrm{~m}$ and has been unmanaged since early 20th century logging. Loss of American chestnut (Castanea dentata) due to chestnut blight (Cryphonectria parasitica) in the 1930s and loss of eastern hemlock (Tsuga canadensis) from hemlock woolly adelgid (Adelges tsugae) infestation in the early 2000s (Ford and others 2012) have been notable disturbances, which have influenced tree species composition in reference watersheds at Coweeta (Elliott and Swank 2008; Ford and others 2012) but have not caused apparent changes in $\mathrm{N}$ dynamics (Swank and Vose 1997; Adams and others 2014). Vegetation on WS 2 is a diverse mixture of deciduous hardwood species including oaks (Quercus spp.), hickories (Carya spp.), yellow poplar (Liriodendron tulipifera), red maple (Acer rubrum), and sweet birch (Betula lenta) with a dense broadleaved understory of rhododendron (Rhododendron maximum) along the stream and mountain laurel (Kalmia latifolia) on dry slopes and ridges.

WS 7, which is 59.5 ha and south facing, was used for a woodland grazing experiment from 1941 to 1949 , but there were no measurable effects of this experiment on flow characteristics or stream chemistry 25 years later (Swank and Douglass 1977). Altitude of WS 7 ranges from 722 to $1077 \mathrm{~m}$, and it is drained by a second-order stream, Big Hurricane Branch. Prior to clearcutting, the forest vegetation on WS 7 was similar to the reference watershed, dominated by oaks, hickories, red maple, yellow poplar, and sweet birch (Boring and others 2014). This watershed was clearcut logged in winter 1977 using a cable-logging system to minimize soil disturbance (Swank and Webster 2014b). Cutting went to the stream edge with no buffer strip, leaving an open canopy over the stream. Tree regrowth was dominated by black locust (Robinia pseudoacacia) during early succession. Within the first 10 years following cutting, black locust made up $20-40 \%$ of the aboveground biomass across the basin, but 10 to 15 years after cutting the biomass of black locust began declining due to mortality caused by locust stem borer (Megacyllene robiniae), and yellow poplar and various oak species now dominate the watershed (Boring and others 2014).

\section{Precipitation and Streamflow}

We measured precipitation with a National Weather Service standard rain gage located adjacent to WS 7 (Coweeta standard rain gage 20, SRG 20) (Laseter and others 2012). Stream discharge for each watershed was measured using sharp-crested $90^{\circ} \mathrm{V}$-notch weirs with continuous flow level recorders (Swift and others 1988; Swank and others 2014).

\section{Nitrogen Input and Export}

Weekly samples for chemical analysis were collected above each weir and from an open-funnel bulk precipitation collector located with SRG 20. 
Inorganic $\mathrm{N}$ inputs (bulk = wet and dry deposition combined) were measured on unfiltered precipitation samples. Nitrate was determined by automated cadmium reduction prior to 1990 and thereafter by ion chromatography, and ammonium was determined by the automated alkaline phenol method (Swank and Vose 1997; Miniat and others 2016). All nitrate samples were analyzed by both cadmium reduction and ion chromatography for a year to insure comparability before permanently changing to ion chromatography.

To calculate monthly and annual mean concentrations, N concentrations were weighted by volume based on weekly precipitation or discharge at the time of sample collection. DIN export for each watershed was calculated using LOADEST (Runkel and others 2004). For WS 2 and WS 7 before clearcutting (1972-1975), we calibrated the DIN versus discharge relationship using combined data for all years ( 42 and 4 years respectively), but for WS 7 post-cutting we calculated export each year separately because of the changing conditions. We used a linear model between $\log$ DIN and log discharge. For WS 2 and WS 7 pre-cutting, October and November were calculated separately. Export was estimated daily using mean daily flow, and daily values were summed to give monthly and annual export.

The calculation of a centroid has been widely used in hydrology as a means to compare the lag between precipitation and stormflow response (for example, Dunne and Leopold 1978; Leopold 1991; Dingman 2015). We calculated a centroid as a way to compare the seasonality of DIN concentration, discharge, and DIN load between watersheds and before and after clearcutting. To calculate the annual centroid of concentration for each year, we added the concentrations for each week and then determined the date when half the concentration sum occurred before that date and half occurred after. The centroids for discharge and DIN export are the dates when one half of the annual discharge or export had occurred. All annual calculations and graphs are based on calendar years.

\section{Statistical Analyses}

We tested for differences in before versus after clearcutting concentrations and export using the paired watershed technique (Hewlett and others 1969). We used linear regression of weekly nitrate, ammonium, and DIN concentrations to establish pre-clearcutting relationships between WS 2 and WS 7. These regression equations were significant $(p<0.001)$ with $r^{2}=0.45, r^{2}=0.48, r^{2}=0.44$, for nitrate, ammonium, and DIN, respectively. These relationships were used to predict post-logging concentrations for WS 7. Predicted and actual concentrations were then compared using paired ttests of weekly concentrations for each year.

We also calculated the linear relationship between pre-clearcutting daily DIN export $(\mathrm{g} / \mathrm{ha})$ for WS 2 and WS 7 (WS $7=0.635^{*}(\text { WS } 2)^{2}+$ $0.863 *($ WS 2$\left.)+0.02, r^{2}=0.97, p<0.0001\right)$. This regression equation was used to predict post-logging daily export for WS 7. Statistical differences in DIN export between actual and predicted values for WS 7 were calculated annually using paired $t$ test comparison of daily values. Differences in centroids were also tested using paired t-tests of annual values or, if the data were not normal, Wilcoxon signed-rank tests were used.

We tested for significant temporal trends in average monthly and annual concentrations, precipitation, stream discharge, $\mathrm{N}$ fluxes (export and input), and centroids for each watershed using Mann-Kendall non-parametric test for trend or Seasonal Kendall non-parametric test for trend with correction for serial correlation (Hirsch and Slack 1984; Helsel and Hirsch 2002; Helsel and others 2006). We used simple linear regression and non-linear regression to test for relationships between variables, and we used dummy variable analysis to compare slopes of linear regression lines.

\section{RESUlts \\ Climate and Hydrology}

Over the 42-year period, precipitation averaged $187 \mathrm{~cm} \mathrm{y}^{-1}$, and had no evidence of trend over time (Figure 1, Seasonal Kendall, $\tau=-0.022$, $p=0.552)$ despite several very wet years and several periods of drought (for example, 1985-1988). Average discharge for WS 2 was $82.5 \mathrm{~cm} \mathrm{y}^{-1}$ and showed no significant trend over time (Figure 1, Seasonal Kendall, $\tau=-0.074, p=0.325)$. Longterm discharge generally followed the precipitation pattern but was highly seasonal, reflecting the seasonal transpiration of the deciduous forest. Discharge from WS 7 was consistently higher than WS 2, averaging $99.9 \mathrm{~cm} \mathrm{y}^{-1}$. This was true during both the pre-cutting (1966-1976) and post-cutting periods and may be because a greater proportion of WS 7 is at a higher altitude than WS 2. WS 14, which is a reference watershed and has very similar area and altitude as WS 7, had average discharge of $99.4 \mathrm{~cm} \mathrm{y}^{-1}$ for the period. For WS 7 there was no 


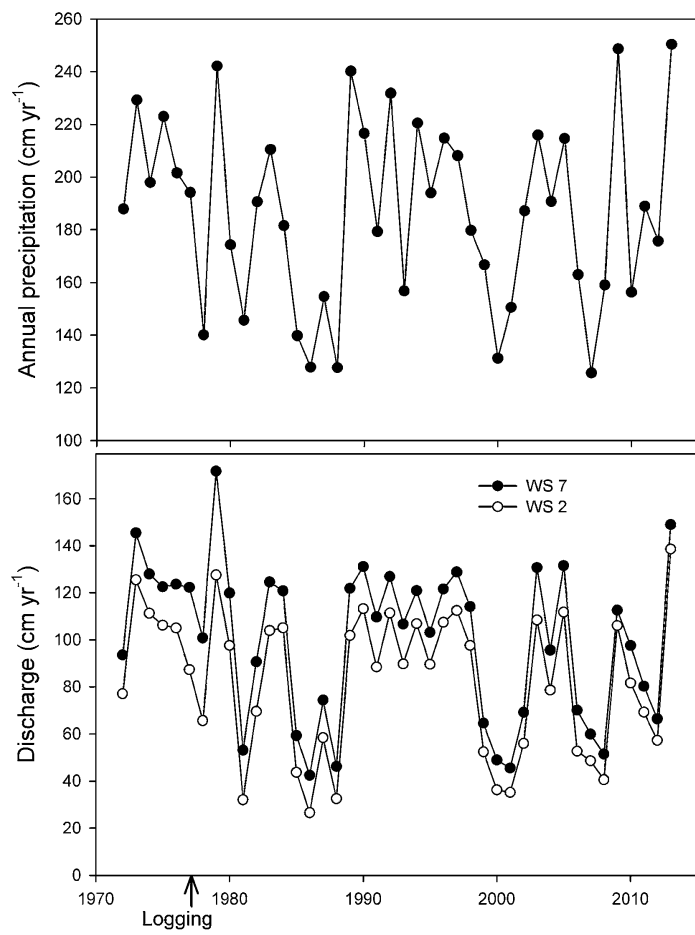

Figure 1. Annual precipitation for Rain Gage 20 and discharge for WS 7 and WS 2 over the past 42 years.

significant trend in discharge with time (Seasonal Kendall, $\tau=-0.154, p=0.0594$ ).

\section{Nitrogen Inputs}

Nitrogen inputs varied both seasonally and long term. The total inorganic $\mathrm{N}$ concentration of bulk precipitation averaged $337 \mu \mathrm{g} \mathrm{L}^{-1}$, peaking in the mid-1990s and generally declining since then. Precipitation $\mathrm{N}$ was made up fairly equally of nitrate (average $=162 \mu \mathrm{g} \mathrm{N} \mathrm{L}^{-1}$ ) and ammonium (average $=148 \mu \mathrm{g} \mathrm{N} \mathrm{L}^{-1}$ ), but the trends of these two constituents were different. Nitrate concentration began decreasing in 1990 (Seasonal Kendall, $\tau=$ $-0.246, p=0.0004)$ coinciding with the passage of the 1990 amendment to the Clean Air Act, while ammonium plateaued and has not changed significantly since that time (Seasonal Kendall, $\tau=0.038$, $p=0.710)$. Total inorganic nitrogen deposition (precipitation concentration times precipitation amount) averaged $5.7 \mathrm{~kg} \mathrm{~N} \mathrm{ha}^{-1} \mathrm{y}^{-1}$, peaked in the 1990s at over $7 \mathrm{~kg} \mathrm{~N} \mathrm{ha}^{-1} \mathrm{y}^{-1}$, and has declined since that time to about $6 \mathrm{~kg} \mathrm{~N} \mathrm{ha}^{-1} \mathrm{y}^{-1}$ (Seasonal Kendall, $\tau=-0.099, p=0.0106)$. Nitrogen concentration in precipitation varies seasonally, peaking in spring/early summer with low concentrations in fall/early winter. Depositional $\mathrm{N}$ input to the watersheds was highest in late winter/early spring and lowest in October.

\section{Nitrogen Export}

For the pre-logging years (1972-1975), average nitrate- $\mathrm{N}$ concentration was significantly higher in WS 2 in 1972 (4.3 vs. $1.9 \mu \mathrm{g} \mathrm{N} \mathrm{L}^{-1}$, paired $t$ test of weekly concentrations, $p=0.03$ ), but for the other three pre-logging years, nitrate concentrations were not significantly different (paired $t$ tests for each year, $p>0.05)$. Ammonium-N and DIN concentrations were not significantly different between WS 7 and WS 2 during the pre-logging years (paired $t$ tests for each year, $p>0.05$ ). Over the whole study period, DIN concentration in WS 2 averaged $9 \mu \mathrm{g} \mathrm{L}^{-1}$ and consisted of slightly more nitrate (average $=5 \mu \mathrm{g} \mathrm{N} \mathrm{L}^{-1}$ ) than ammonium (average $=4 \mu \mathrm{g} \mathrm{N} \mathrm{L}^{-1}$ ). There was a small but significant increasing trend in DIN concentration over the 42-year period (Figure 2, Seasonal Kendall, $\tau=0.314, p=0.0001$ ).

Following clearcutting, WS 7 DIN concentration increased to about $100 \mu \mathrm{g} \mathrm{N} \mathrm{L}^{-1}$ followed by the expected recovery (Figure 2). However, since 1982 there has been a long-term increase in DIN concentration (Seasonal Kendall, $\tau=0.236, \quad p=$ 0.0372 ) with considerable variability (Figure 2 ). This increase in DIN was largely due to an increase in nitrate (Figure 2) as ammonium did not change. For all post-logging years, nitrate and DIN concentrations were significantly higher in WS 7 than the predicted concentrations (paired $t$ tests for each year, $p<0.0001)$. Ammonium concentrations were slightly lower than predicted (3.9 vs. $4.5 \mu \mathrm{g} \mathrm{N} \mathrm{L}^{-1}$ ) over the whole post-logging period, significantly lower most years from 1978 through 2003 (paired $t$ tests for each year).

DIN export before clearcutting was slightly but significantly higher from WS 7 than from WS 2 (73.6 vs. $67.1 \mathrm{~g} \mathrm{~N} \mathrm{ha}^{-1} \mathrm{y}^{-1}$, paired $t$ test each year, $p<0.0001)$ because of higher area-normalized discharge. After clearcutting (1978-2013), export from WS 7 was always higher than from WS 2 (998.0 vs. $73.5 \mathrm{~g} \mathrm{~N} \mathrm{ha}^{-1} \mathrm{y}^{-1}$ ) and significantly higher each year than the predicted export based on the paired watershed approach (Figure 3, paired t-test each year, $p<0.0001)$. This difference was primarily due to the difference in DIN concentration, since discharge for WS 7 was only elevated for a few years (Figure 1).

Coweeta streams exhibit a strong seasonal pattern in DIN concentration. In WS 2, DIN was lowest in winter, increased in spring to a peak in late summer, and then decreased rapidly with leaf fall in autumn (Figure 4). Before clearcutting, the pattern in WS 7 was similar, but since clearcutting there has been a pattern of high winter-spring DIN 


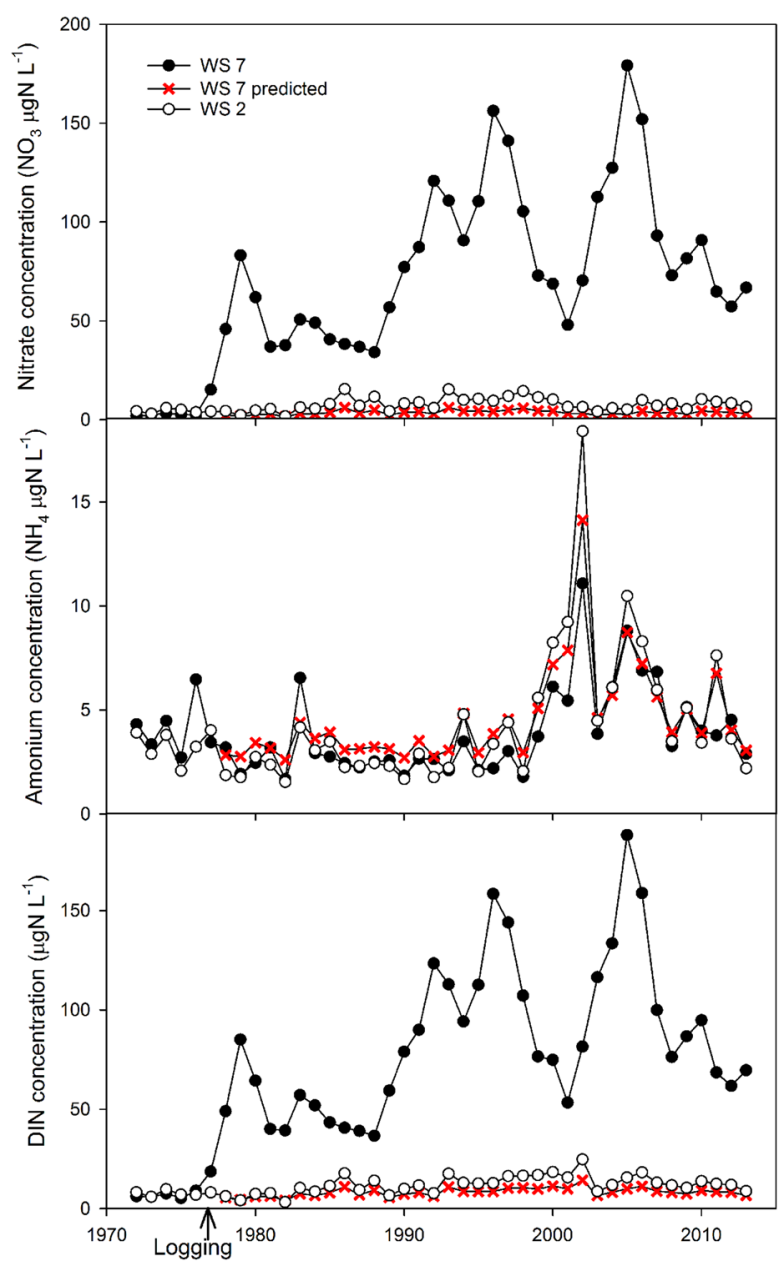

Figure 2. Annual average flow-weighted streamwater nitrate (upper panel), ammonium (middle panel), and DIN concentration (lower panel) over the past 42 years. In each panel, the solid symbols are measured concentrations in WS 7, and the open symbols are measured concentrations in WS 2. The red $\times$ 's are the predicted post-logging concentrations for WS 7 based on the prelogging relationship between WS 7 and WS 2 .

concentration and a late summer/fall decline followed immediately by rapidly increasing concentration (Figure 4).

The centroids of DIN concentration occurred in mid/late-summer for reference WS 2 and there was no evidence of a long-term trend in the data (Figure 5, Mann-Kendall, $p>0.05)$. Before cutting, the pattern in WS 7 was similar, but after cutting, the DIN concentration centroid shifted to a significantly earlier date than WS 2 (Figure 5, Wilcoxon signed-rank test, $p<0.001$ ). From 1979 to 1983, the centroid for WS 7 concentration moved to later in the year (Figure 5, Mann-Kendall, $\tau=0.348$, $p=0.0034)$. Since 1984, there has been no significant trend in the DIN concentration centroid for WS 7 (Mann-Kendall, $\tau=0.149, p=0.25$ ).

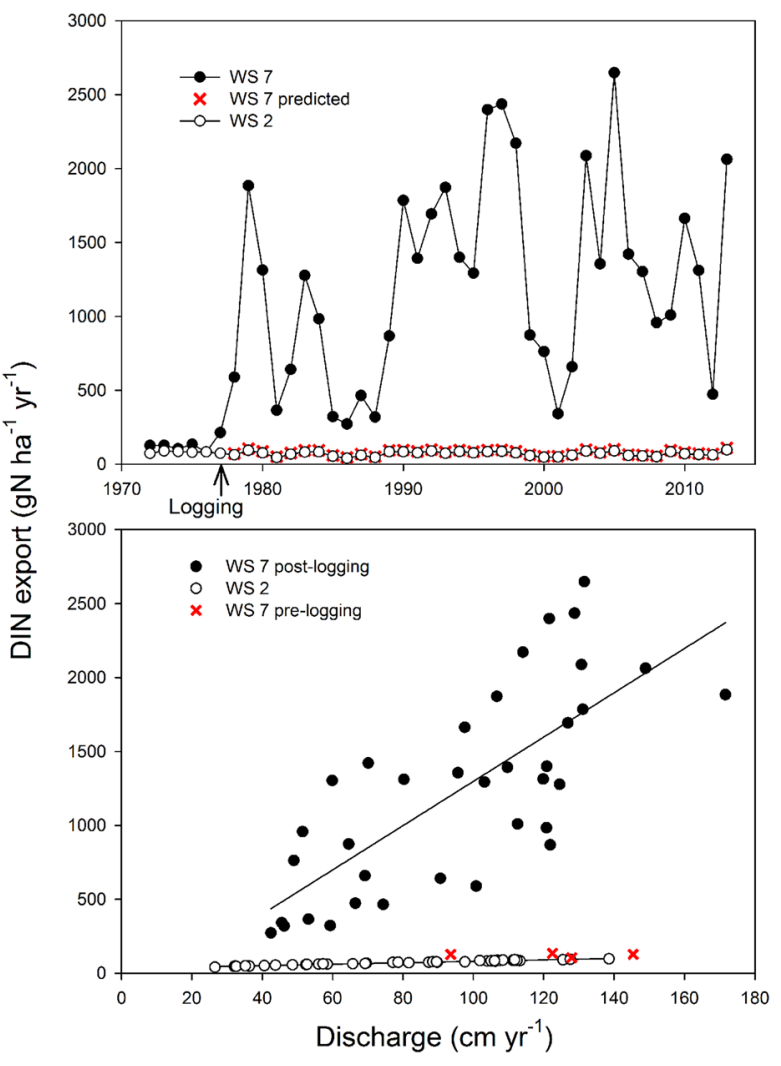

Figure 3. Upper panel annual DIN export for WS 2 and WS 7 over the past 42 years and WS 7 predicted for the post-logging period. Most of the points for WS 7 predicted are hidden behind the WS 2 points. Lower panel DIN export for WS 2 and WS 7 as a function of discharge. Lines are regression lines (WS 2: $y=32.8+0.489 x$, $r^{2}=0.98, p<0.001$; WS $7: y=-199+15.0 x, r^{2}=0.56$, $p<0.001)$. The red symbols are pre-cutting years for WS 7 and were not included in the regression.

The centroids for stream discharge were similar for both WS 2 and WS 7 before and after clearcutting, (Figure 5). The WS 7 discharge centroid averaged 12 days earlier than WS 2 (Wilcoxon Signed-Rank test, $p<0.001$ ); however, there was no change following clearcutting.

Before logging, the centroids of DIN export for WS 7 and WS 2 were not significantly different (paired $t$ test, $p=0.14$ ). Following clearcutting, more of the DIN export occurred earlier in the year (Figure 5) and the centroid for WS 7 export was significantly earlier than that of WS 2 (paired $t$ test, $p<0.0001)$.

\section{Relationship between DIN Concentration and Export and Discharge}

We found a distinct change in the relationship between annual DIN export and annual discharge (Figure 3). DIN export was calculated using stream 


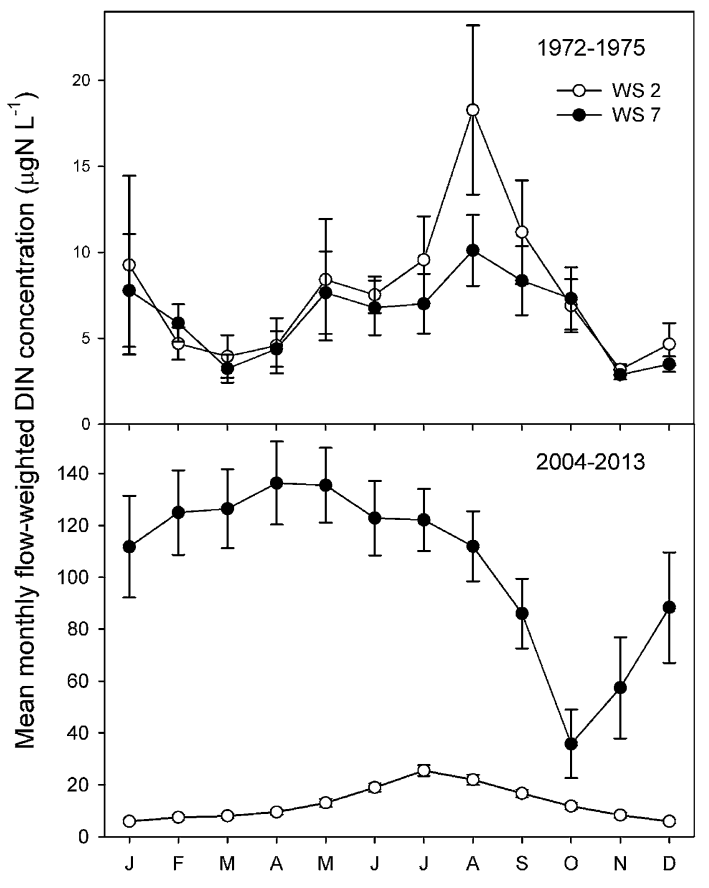

Figure 4. Average $( \pm S E)$ flow-weighted monthly DIN concentration for WS 2 and WS 7 before clearcutting (1972-1975, upper panel) and for the most recent 10 years (2004-2013, lower panel). Error bars for WS 2 in the lower panel are mostly smaller than the symbols.

discharge; therefore, the relationships between export and discharge were significantly positive for both WS 2 and WS 7; however, the slopes were very different (dummy variable analysis, $p<0.0001)$. For WS 2, annual DIN export increased $0.5 \mathrm{~g} \mathrm{~N} \mathrm{ha}^{-1}$ for every $1 \mathrm{~cm}$ increase in discharge, and the export-discharge relationship for WS 7 was very similar before clearcutting (Figure 3). In contrast, after clearcutting DIN export from WS 7 increased by $15 \mathrm{~g} \mathrm{~N} \mathrm{ha}^{-1}$ for every $1 \mathrm{~cm}$ increase in discharge.

We tested for a change in the stream discharge and DIN concentration relationship from being source limited (negative $b$ coefficient) to transport limited (positive $b$ coefficient) by fitting equation (1) to weekly DIN concentration and discharge (area normalized) for the entire 42-year period in WS 2 and for the post-clearcutting period (19782013) WS 7. For WS 2 , the slope of the $\log -\log$ DIN concentration-discharge relationship was negative (Figure 6, non-linear regression, $b=-0.423$, $\left.r^{2}=0.176, p<0.0001\right)$. However, for WS 7, the DIN concentration-discharge relationship had a significant positive relationship (non-linear regression for post-cutting 1978-2013 data, $\left.b=0.462, r^{2}=0.289, p<0.0001\right)$. The slope of the concentration-discharge relationship for WS 7

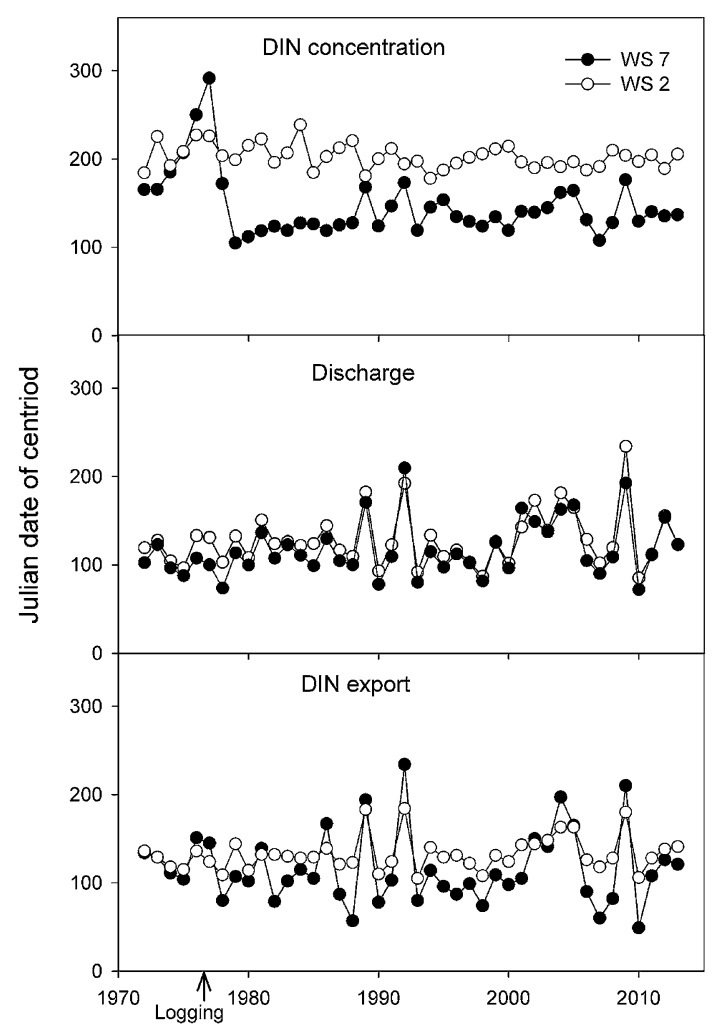

Figure 5. Julian dates of the centroids of DIN concentration, discharge, and DIN export for WS 7 and WS 2 over the past 42 years.

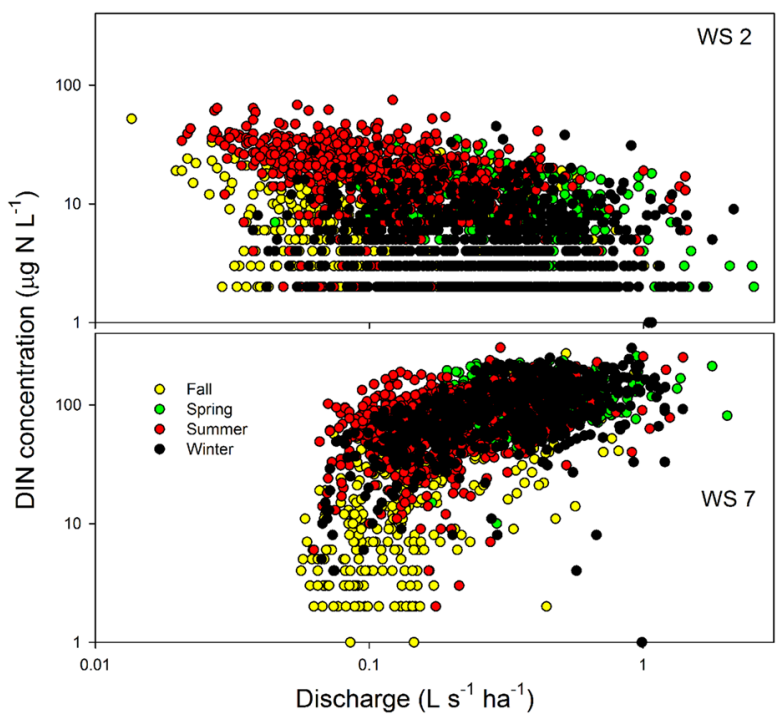

Figure 6. Concentration-discharge graphs for WS 7 and WS 2. Each point is a weekly measurement of DIN and the discharge at the time of sample collection. WS 2 data are from 1972 through 2013. WS 7 data only include the post-clearcutting period, 1978-2013. Discharge is normalized to watershed area. 
was significantly different than the slope for WS 2 (post-cut data only, dummy variable analysis on log-transformed concentration and discharge data, $p<0.0001)$.

\section{Discussion}

In many ways, the recovery of WS 7 from clearcut logging was rapid. For example, trees grew back rapidly - within 10 years, leaf area index was similar to pre-logging, and within 30 years total aboveground biomass exceeded precut estimates (Boring and others 2014). Similarly, the canopy coverage of the stream recovered rapidly with allochthonous inputs reaching that of reference streams within 10 years (Webster and others 2014a). Also, the paired watershed technique (Hewlett and others 1969) showed that annual discharge increased $30 \mathrm{~mm}$ above predicted levels immediately following cutting in 1977 and remained elevated for several years. But as vegetation regrowth occurred, discharge declined and had returned to predicted levels within about 7 years (Swank and others 2014), consistent with other studies at Coweeta (Swift and Swank 1981; Swank and others 1988). However, discharge since 1985 has been both greater than and less than expected, suggesting that either structural changes of the regrowing vegetation, species compositional changes, or both are affecting evapotranspiration in WS 7 (Ford and others 2011). In addition, stream N export remains elevated with no indication of returning to pre-logging levels, seasonal $\mathrm{N}$ export patterns are different than before clearcutting, and $\mathrm{N}$ export appears to be hydrologically controlled rather than biologically controlled.

\section{Effect of Clearcutting on DIN Export}

Based on previous studies (for example, Likens and others 1977; Hornbeck and others 2014), we expected the increased export of $\mathrm{N}$ from WS 7 in the first few years after cutting (Figure 3), followed by a rapid recovery and perhaps even a mid-successional period when $\mathrm{N}$ export would be even less than that of a reference watershed due to the rapidly aggrading forest (Vitousek and Reiners 1975; Martin and others 2000). Such mid-successional retention of nutrients has been seen in studies of cation budgets for Coweeta watersheds (Johnson and Swank 1973). After peak N export, we saw the expected trend of decreasing DIN (Swank 1986), but then, approximately 10 years after cutting, DIN export increased, reaching levels well above the initial response to cutting (Figure 3).
Other watersheds at Coweeta that were deforested through intensive experimental treatments also suggest a regime shift in DIN export. All trees on WS 6 were cut in 1958, and the logging residue was stacked and burned. The watershed was planted with pasture grasses, limed, and fertilized, and the grass was maintained through 1967. When the site was then herbicided and allowed to go through old field succession, the vegetation was dominated by black locust for the next 30 years (Johnson and Swank 1973; Swank 1986; Swank and Vose 1997). Stream nitrate concentration in this watershed has consistently been in the range of 500 to $1000 \mu \mathrm{g} \mathrm{N} \mathrm{L}^{-1}$ (Swank 1986; Swank and Vose 1997; Davidson and Swank 1986) and increased significantly from 1972 through 1994 (Swank and Vose 1997). Another example is WS 17, which was clearfelled without wood removal in 1940, repeatedly cleared from 1941 to 1956 , and then planted in white pine. DIN concentration in the stream draining WS 17 remains well above the adjacent reference watershed, and the long-term pattern of DIN export is almost identical to that of WS 7 (Adams and others 2014).

Part of the explanation for the high export of DIN from WS 7 is the high level of input from $\mathrm{N}$ fixing bacteria associated with black locust. Based on studies of black locust leaf decomposition, White and others (1988) concluded that much of the symbiotically fixed $\mathrm{N}$ ends up as recalcitrant soil organic matter. The importance of $\mathrm{N}$ fixation in watershed studies has been noted for watersheds with high density of red alder (Van Miegroet and Cole 1985; Bechtold and others 2003; Perakis and Sinkhorn 2011) and abundant lichens (Sollins and others 1980). Additionally, Perakis and others (2015) found that patterns of $\delta^{15} \mathrm{~N}$ in the Oregon Cascade Mountains were clearly related to the legacy of $\mathrm{N}$ fixation associated with snowbush (Ceanothus velutinus) dominance following logging. Boring and others (1988) estimated that $\mathrm{N}$ fixation in WS 7 was as much as $200 \mathrm{~kg} \mathrm{~N} \mathrm{ha}^{-1}$ over the approximate 20-year lifespan of black locust. However, this input of $\mathrm{N}$ has been approximately balanced by forest growth during this time period-Boring and others (2014) reported an increase in aboveground vegetation of $198 \mathrm{~kg} \mathrm{~N} \mathrm{ha}^{-1}$ between 1979 and 1997. In 2002, Knoepp and others (2015) estimated that black locust continued to contribute approximately $3.9 \mathrm{~kg} \mathrm{ha}^{-1} \mathrm{y}^{-1}$ to the forest floor. Following logging, there was also a slash residue of $314 \mathrm{~kg} \mathrm{~N} \mathrm{ha}^{-1}$ left on the forest floor (Boring and others 2014). The $\mathrm{N}$ in the upper $30 \mathrm{~cm}$ of soil increased by about $360 \mathrm{~kg} \mathrm{~N} \mathrm{ha}^{-1}$ just 2 years after logging (Knoepp and others 2014) 
presumably a result of decomposition of this logging debris and roots mortality coupled with a lack of autotrophic uptake. Since that peak in 1979, total soil $\mathrm{N}$ has decreased substantially (Knoepp and others 2014). Examination of patterns of $\delta^{15} \mathrm{~N}$ in the soil profile showed that this organic matter has moved through the soil profile (Knoepp and others 2015). We submit that the large pulse of nitrogen lost from the upper $30 \mathrm{~cm}$ of soil moved into deep soil layers $(>30 \mathrm{~cm})$ and that this $\mathrm{N}$ is slowly moving to the stream.

Lovett and Goodale (2011) suggested using a mass balance approach to quantify forest $\mathrm{N}$ saturation by examining $\mathrm{N}$ inputs, $\mathrm{N}$ accumulation in soils and vegetation, and $\mathrm{N}$ losses. They suggested that $\mathrm{N}$ saturation occurs both when $\mathrm{N}$ input rates exceed rates of $\mathrm{N}$ accumulation (kinetic saturation) and when sinks reach their capacity for $\mathrm{N}$ accumulation (capacity saturation). For WS 7 , the N inputs from logging slash residue, roots, and soil organic matter, black locust $\mathrm{N}$ fixation, and atmospheric deposition significantly exceed soil retention and vegetation uptake resulting in increased stream export and clearly suggesting kinetic $\mathrm{N}$ saturation. The movement of this $\mathrm{N}$ to the stream is dependent on hillslope to stream hydrologic connectivity (Jencso and others 2009). The change in both the source of $\mathrm{N}$, from surface to deep soils, and the role of hydrologic connectivity between the soils and the stream is suggested by the altered relationship between export and discharge (Figure 3).

\section{Effect of Clearcutting on the Seasonal Pattern of DIN Concentration and Export}

Stoddard (1994) and Ohte (2012) suggested that seasonality of stream DIN concentration and export is an important diagnostic indicator of watershed nitrogen dynamics. Before clearcutting, WS 7 had a pattern of winter low and summer high DIN concentrations similar to reference watersheds at Coweeta, but we found very clear changes in DIN seasonality as a result of clearcutting WS 7 . The most recent measurements show that in-stream leaf decomposition rates in WS 7 are still much faster than in a reference stream draining a northfacing reference (Webster and others 2014a). This may be due in part to higher stream DIN concentrations, but it also shortens the time when there is net uptake of $\mathrm{N}$ by the leaf-associated microbes. With the high input of nitrogen to the stream from the terrestrial system, these in-stream processes appear to have little influence on the seasonality of DIN (Lin and others 2015) except for the brief de- cline of DIN in early fall (Figure 4). There has been no significant change in the seasonal pattern for WS 7 since 3 years after clearcutting as shown by the lack of trend in the centroids of either DIN concentration or DIN export.

\section{Clearcutting Effects on the Relationship between DIN Concentration and Discharge}

The relationship between DIN concentration and stream discharge in WS 7 has been very different than the reference watershed (Figure 6) since WS 7 was clearcut. We found a significant positive relationship between concentration and discharge for WS 7, the opposite of the relationship in WS 2. This positive relationship may be the result of low flows in fall when maximum in-stream $\mathrm{N}$ uptake occurs or because streamflow becomes dominated by deep groundwater, which has low DIN concentrations (Rhett Jackson, University of Georgia, personal communication). However, even with fall data removed, the relationship remains statistically significant (non-linear regression, $b=0.365, r^{2}=$ $0.218, p<0.0001)$. Ocampo and others (2006) described switching between hydrologic and biogeochemical control of nutrient export at event, seasonal, and inter-annual scales and suggested this switch was primarily related to temporal variability in aquifer connectivity. Similarly, Vaché and others (2015) discussed the N control capacity of watershed components in an old-growth forest in Oregon. In the Mediterranean climate of the Pacific Northwest, vegetation and soil processes have the primary control on $\mathrm{N}$ export during summer when there is little precipitation. Hydrologic flushing becomes much more important during the nongrowing season. In WS 7, we see this switch in regulation of $\mathrm{N}$ export occurring at a decadal time scale. Worrall and others (2003) suggested that as a result of the increased $\mathrm{N}$ availability following clearcutting, export from WS 7was no longer supply limited but transport limited.

\section{Linking Stream Response to Ecosystem Processes}

Several questions remain regarding the links between high $\mathrm{N}$ export from WS 7 and the ecosystem processes related to this export. First, what is the source of the $\mathrm{N}$ that continues to be exported from WS 7? We think this $\mathrm{N}$ originally came from atmospheric $\mathrm{N}$ fixation by black locust symbionts and from the decomposition and mineralization of logging debris, dead roots, and soil organic matter. 
This $\mathrm{N}$ is not now apparent in total $\mathrm{N}$ concentrations of bulk soil samples collected from the upper $30-\mathrm{cm}$ of soil but is evident in $\delta^{15} \mathrm{~N}$ values in soils at depths greater than $30 \mathrm{~cm}$ (Knoepp and others 2015). Perhaps this $\mathrm{N}$ has accumulated not only deeper in the soil profile but also in highly discrete areas such as near the stream channel (Perakis 2002; Johnson and Turner 2014).

Second, if the changes we describe as a regime shift in $\mathrm{N}$ export were initiated by logging, why does the response differ from the reference watersheds that were logged in the 1920s? Current stream $\mathrm{N}$ concentration data for reference watersheds at Coweeta do not suggest a regime shift in response to the earlier logging (Adams and others 2014; USDA Forest Service, Coweeta Hydrologic Laboratory, unpublished data). Perhaps the answer lies in the fact that the selective logging that occurred in the 1920s only removed approximately $30 \%$ of the basal area (Douglass and Hoover 1988; Elliott and Swank 2008). As a result, there was not the large response by black locust as seen in WS 7 clearcutting. In the 1934-1935 vegetation survey, forests were dominated by oak/hickory forest and black locust basal area averaged $0.57 \mathrm{~m}^{2} \mathrm{ha}^{-1}$ throughout the Coweeta basin (Elliott and Swank 2008). In comparison, black locust basal area ranged from 8.2 to $52.1 \mathrm{~m}^{2} \mathrm{ha}^{-1}$ in clearcut areas from 4 to 38 years old (Boring and Swank 1984). Following black locust mortality, clearcut areas become dominated by yellow poplar, and $\mathrm{N}$ cycling processes differ significantly in these yellow poplardominated forests compared to mixed oak forest, exhibiting lower forest floor and soil C: $\mathrm{N}$ ratios and higher rates of $\mathrm{N}$ mineralization and nitrification (Knoepp and others 2000).

The third question, is this a regime shift or just a long-term response? Identification of a regime shift is difficult (Carpenter and Brock 2006) because it implies that the ecosystem will never return to the pre-disturbance state. For a system such as a lake with relatively rapid dynamics, identification of a regime shift may be reliably concluded within a 10to 20-year period, but dynamics are much slower in a forest making it difficult to distinguish a regime shift from a very slow recovery (Standish and others 2014). If we had terminated stream $\mathrm{N}$ measurements after only 10 years, we probably would have concluded that the ecosystem was rapidly recovering to the original state. Based on nearly 40 years of post-clearcutting measurement, our data suggest that although vegetation is rapidly growing, there is no recovery trend in stream DIN concentration or export for WS 7. If these measurements are continued for another 50 or more years, the next generation of ecologists might reach different and more definitive conclusions.

What are the feedbacks that maintain the new stability regime? If the new regime is stable, what is the "unhelpful resilience" that keeps the ecosystem from returning to the pre-logging condition (Standish and others 2014)? N export from watersheds at Coweeta has recovered rapidly from small disturbances, including hurricanes, fires, forest insect and disease infestations, grazing, and selective logging, but this has not been the case for clearcutting recovery. Previous research concluded that rapid forest regrowth was the major feedback mechanism responsible for recovery. Export of DIN from reference watersheds at Coweeta was consistently less than $2 \%$ of $\mathrm{N}$ deposition, even throughout periods of high $\mathrm{N}$ deposition. $\mathrm{N}$ inputs were either immobilized by trees, converted to organic matter, stabilized by soil microbial activity, or lost through denitrification or other gaseous losses. The feedback mechanisms that maintain the current high $\mathrm{N}$ export regime of WS 7 could be related not only to the change in vegetation composition but also to $\mathrm{N}$ stored within the watershed, perhaps in locations that are hydrologically connected to the stream during much of the year.

\section{Summary}

In the original proposal to study WS 7 response to clearcutting, it was predicted that recovery from this disturbance would be rapid and that cutting would not cause an ecosystem regime shift (Monk and others 1977; Webster and others 2014b). However, it is now evident that, at least in terms of $\mathrm{N}$ export, WS 7 is very different than it was before cutting and very different than reference watersheds. Worrall and others (2003) concluded that the change to WS 7 could only be reset by massive management intervention. If left unmanaged, the future state of WS 7 is unclear. Whether we view this as a regime change, a dynamic situation, or simply a very slow recovery, a tenfold increase in $\mathrm{N}$ export is ecologically interesting but may have little downstream impact. The current DIN concentration in Big Hurricane Branch (WS 7) of around $100 \mu \mathrm{g} \mathrm{N} \mathrm{L}^{-1}$ is high relative to reference watersheds at Coweeta and other areas of the southern Appalachians, but it is low compared to streams draining agricultural or developed watersheds in the region (Webster and others 2012) and streams in most other parts of the country and does not present a water quality issue; USEPA drinking water standards are $2300 \mu \mathrm{g} \mathrm{L} \mathrm{L}^{-1}$. However, our results illustrate the permanent or at least long- 
term changes in ecosystems that may result from forest disturbance. They suggest the need for forward-looking management that aims to increase the resilience of forests and create or maintain desired nutrient cycling regimes (Pace and others 2015).

\section{ACKNOWLEDGEMENTS}

We thank Bobbie Niederlehner for help with the statistical analyses. Many of the ideas in this paper resulted from discussions with Drs. Rhett Jackson, Durrell Scott, Stephen Schoenholtz, Jeb Barrett, Kevin McGuire, Brian Strahm, Mary Beth Adams, Sheila Christopher, and Charley Kelly. We also appreciate the helpful comments from two anonymous reviewers. The WS 7 study was supported by the USDA Forest Service, Southern Research Station, Coweeta Hydrologic Laboratory, and by a series of grants from the National Science Foundation. This analysis of long-term data was supported by NSF grant DEB0823293 to the Coweeta LTER program at the University of Georgia and by Coweeta Hydrologic Laboratory.

\section{REFERENCES}

Aber JD, Nadelhoffer KJ, Steudler P, Melillo JM. 1989. Nitrogen saturation in northern forest ecosystems. Bioscience 39:37886.

Aber JD, Ollinger SV, Driscoll CT, Likens GE, Holmes RT, Freuder RJ, Goodale CL. 2002. Inorganic nitrogen losses from a forested ecosystem in response to physical, chemical, biotic, and climatic perturbations. Ecosystems 5:648-58.

Adams MB, Knoepp JD, Webster JR. 2014. Inorganic nitrogen retention by watersheds at Fernow Experimental Forest and Coweeta Hydrologic Laboratory. Soil Sci Soc Am J 78:S84-94.

Adams MB, Kochendenfer JN. 2014. Recovery of central Appalachian forested watersheds. In: Swank WT, Webster JR, Eds. Long-term response of a forest watershed ecosystem. Clearcutting in the southern Appalachians. Oxford: Oxford University Press. p 194-212.

Auberton GM, Patric JH. 1974. Water quality after clearcutting a small watershed in West Virginia. J Env Qual 3:243-9.

Band LE, Tague CL, Groffman P, Belt K. 2001. Forest ecosystem processes at the watershed scale: hydrological and ecological controls of nitrogen export. Hydrol Process 15:2013-28.

Basu NB, Destouni G, Jawitz JW, Thompson SE, Loukinova NV, Darracq A, Zanardo S, Yaeger M, Sivapalan M, Rinaldo A, Rao PSC. 2010. Nutrient loads exported from managed catchments reveal emergent biogeochemical stationarity. Geophys Res Lett. doi:10.1029/2010GL045168.

Bechtold JS, Edwards RT, Naiman RJ. 2003. Biotic versus hydrologic control over seasonal nitrate leaching in a floodplain forest. Biogeochemistry 63:53-71.

Bernal S, von Schiller D, Martí E, Sabater F. 2012. In-stream net uptake regulates inorganic nitrogen export from catchments under base flow conditions. J Geophys Res 117:G00N05.
Bernhardt ES, Likens GE, Buso DC, Driscoll CT. 2003. In-stream uptake dampens effects of major forest disturbance on watershed nitrogen export. Proc Natl Acad Sci USA 100:10304-8.

Bernhardt ES, Likens GE, Hall ROJ, Buso DC, Fischer SG, Burton TM, Meyer JL, McDowell WH, Mayer MS, Bowden WB, Findlay SEG, Macneale KH, Stelzer RS, Lowe WH. 2005. Can't see the forest for the stream? In-stream processing and terrestrial nitrogen exports. Bioscience 55:219-30.

Boring LR, Elliott KJ, Swank WT. 2014. Successional forest dynamics. In: Swank WT, Webster JR, Eds. Long-term response of a forest watershed ecosystem. Clearcutting in the southern Appalachians. Oxford: Oxford University Press. p $11-35$.

Boring LR, Swank WT. 1984. Symbiotic nitrogen fixation in regenerating black locust (Robinia pseudoacacia L.) stands. For Sci 30:528-37.

Boring LR, Swank WT, Waide JB, Henderson GS. 1988. Sources, fates, and impacts of nitrogen inputs to terrestrial ecosystems: review and synthesis. Biogeochemistry 6:119-59.

Bormann FH, Likens GE. 1979a. Pattern and process in a forested ecosystem. New York: Springer.

Bormann FH, Likens GE. 1979b. Catastrophic disturbance and the steady state in northern hardwood forests. Am Sci 67:6609 .

Bredemeier M, Blanck K, Lamersdorf N, Wiedey GA. 1995. Response of soil-water chemistry to experimental clean rain in the Nitrex roof experiment at Selling, Germany. Forest Ecol Manag 71:31-44.

Brookshire ENJ, Gerber S, Webster JR, Vose JM, Swank WT. 2011. Direct effects of temperature on forest nitrogen cycling revealed through analysis of long-term watershed records. Glob Change Biol 17:297-308.

Burns DA. 1998. Retention of $\mathrm{NO}_{3}{ }^{-}$in an upland stream environment: a mass balance approach. Biogeochemistry 40:7396.

Carpenter SR, Brock WA. 2006. Rising variance: a leading indicator of ecological transition. Ecol Lett 9:308-15.

Carpenter SR, Ludwig D, Brock WA. 1999. Management of eutrophication for lakes subject to potentially irreversible change. Ecol Appl 9:751-71.

Collie JS, Richardson K, Steele JH. 2004. Regime shifts: can ecological theory illuminate the mechanisms? Prog Oceanogr 60:281-302.

Corre MD, Lamersdorf NP. 2004. Reversal of nitrogen saturation after long-term deposition reduction: impact on soil nitrogen cycling. Ecology 85:3090-104.

Creed IF, Band LE, Foster NW, Morrison IK, Nicolson JA, Semkin RS, Jeffries DS. 1996. Regulation of nitrate-N release from temperate forests: a test of the $\mathrm{N}$ flushing hypothesis. Wat Resour Res 32:3337-54.

Davidson EA, Swank WT. 1986. Environmental parameters regulating gaseous nitrogen losses from two forested ecosystems via nitrification and denitrification. Appl Environ Microbiol 52:1287-92.

Dent CL, Cumming GS, Carpenter SR. 2002. Multiple states in river and lake ecosystems. Philos Trans R Soc B 357:635-45.

Dingman SL. 2015. Physical hydrology. Long Grove: Waveland Press.

Dise NB, Wright RF. 1995. Nitrogen leaching from European forests in relation to nitrogen deposition. Forest Ecol Manag $71: 153-61$. 
Douglass JE, Hoover MD. 1988. History of Coweeta. In: Swank WT, Crossley DA, Eds. Forest hydrology and ecology at Coweeta. New York: Springer. p 17-31.

Dunne T, Leopold LB. 1978. Water in environmental planning. San Francisco: Freeman.

Elliott KJ, Swank WT. 2008. Long-term changes in forest composition and diversity following early logging (1919-1923) and the decline of American chestnut (Castanea dentata). Plant Ecol 197:155-72.

Eshleman KN, Sabo RD, Kline KM. 2013. Surface water quality is improving due to declining atmospheric $\mathrm{N}$ deposition. Environ Sci Technol 47:12193-200.

Ford CR, Hubbard RM, Vose JM. 2011. Quantifying structural and physiological controls on variation in canopy transpiration among planted pine and hardwood species in the southern Appalachians. Ecohydrology 4:183-95.

Ford CR, Elliott KJ, Clinton BD, Kloeppel BD, Vose JM. 2012. Forest dynamics following eastern hemlock mortality in the southern Appalachians. Oikos 121:523-36.

Gholz HL, Hawk GM, Campbell A, Cromack K, Brown AT. 1985. Early vegetation recovery and element cycles on a clear-cut watershed in western Oregon. Can J For Res 15:400-9.

Godsey SE, Kirchner JW, Clow DW. 2009. Concentration-discharge relationships reflect chemostatic characteristics of US catchments. Hydrol Process 23:1844-64.

Goodale CL, Thomas SA, Fredriksen G, Elliott EM, Flinn KM, Butler TJ, Walter MT. 2009. Unusual seasonal patterns and inferred processes of nitrogen retention in forested headwaters of the Upper Susquehanna River. Biogeochemistry 93:197-218.

Groffman P, Baron J, Blett T, Gold A, Goodman I, Gunderson L, Levinson B, Palmer M, Paerl H, Peterson G, Poff N, Rejeski D, Reynolds J, Turner M, Weathers K, Wiens J. 2006. Ecological thresholds: the key to successful environmental management or an important concept with no practical application? Ecosystems 9:1-13.

Gunderson LH. 2000. Ecological resilience-in theory and application. Annu Rev Ecol Syst 31:425-39.

Helsel D, Hirsch R. 2002. Statistical methods in water resources. In: Techniques of water resources investigations, Book 4, Chap A3. US Geological Survey.

Helsel DR, Mueller DK, Slack JR. 2006. Computer program for the Kendall family of trend tests. U.S. Geological Survey Scientific Investigation Report 2005-5275.

Hewlett JD, Lull HW, Reinhart KG. 1969. In defense of experimental watersheds. Water Resour Res 5:306-16.

Hirsch RM, Slack JR. 1984. A nonparametric trend test for seasonal data with serial dependence. Water Resour Res 20:727-32.

Holling CS. 1973. Resilience and stability of ecological systems. Annu Rev Ecol Syst 4:1-24.

Hornbeck JW, Bailey AS, Eager C, Campbell JL. 2014. Comparisons with results from the Hubbard Brook Experimental Forest in the northern Appalachians. In: Swank WT, Webster JR, Eds. Long-term response of a forest watershed ecosystem. Clearcutting in the southern Appalachians. Oxford: Oxford University Press. p 213-28.

Hornberger GM, Bencala KE, McKnight DM. 1994. Hydrological controls on dissolved organic carbon during snowmelt in the Snake River near Montezuma, Colorado. Biogeochemistry 25:147-65.

Jencso KG, McGlynn BL, Gooseff MN, Wondzell SM, Bencala KE, Marshall LA. 2009. Hydrologic connectivity between landscapes and streams: transferring reach-and plot-scale understanding to the catchment scale. Water Resour Res 45:W04428.

Johnson DW, Turner J. 2014. Nitrogen budgets of forest ecosystems: a review. For Ecol Manag 318:370-9.

Johnson EA. 2002. Industrial destruction reversed at Copper Basin. Nat Woodl 25(10-13):29.

Johnson PL, Swank WT. 1973. Studies of cation budgets in the southern Appalachians on four experimental watersheds with contrasting vegetation. Ecology 54:70-80.

Knoepp JD, Coleman DC, Crossley DA, Clark JS. 2000. Biological indices of soil quality; an ecosystem case study of their use. Forest Ecol Manag 138:357-68.

Knoepp JD, Swank WT. 1998. Rates of nitrogen mineralization across an elevation and vegetation gradient in the southern Appalachians. Plant Soil 204:235-41.

Knoepp JD, Swank WT, Haines BL. 2014. Long- and short- term changes in nutrient availability following commercial sawlog harvest via cable logging. In: Swank WT, Webster JR, Eds. Long-term response of a forest watershed ecosystem. Clearcutting in the southern Appalachians. Oxford: Oxford University Press. p 57-84.

Knoepp JD, Taylor RS, Boring LR, Miniat CF. 2015. Influence of forest disturbance on stable nitrogen isotope ratios in soil and vegetation profiles. Soil Sci Soc Am J. doi:10.2136/sssaj2015. 03.0101 .

Laseter SH, Ford CR, Vose JM, Swift LW. 2012. Long-term temperature and precipitation trends at the Coweeta Hydrologic Laboratory, Otto, North Carolina, USA. Hydrol Res 43:890-901.

Leopold LB. 1991. Lag times for small drainage basins. Catena 18:157-71.

Lewontin RC. 1969. The meaning of stability. Brookhaven Symp Biol 22:13-24.

Likens GE, Bormann FH, Johnson NM, Fisher DW, Pierce RS. 1970. The effects of forest cutting and herbicide treatment on nutrient budgets in the Hubbard Brook watershed-ecosystem. Ecol Monogr 40:23-47.

Likens GE, Bormann FH, Pierce RS, Eaton JS, Johnson NM. 1977. Biogeochemistry of a forested ecosystem. New York: Springer.

Lin L, Webster JR, Hwang T, Band LE. 2015. Effects of lateral nitrate flux and instream processes on dissolved inorganic nitrogen export in a forested catchment: a model sensitivity analysis. Water Resour Res 51:2680-95.

Lovett G, Goodale C. 2011 . A new conceptual model of nitrogen saturation based on experimental nitrogen addition to an oak forest. Ecosystems 14:615-31.

Lutz BD, Mulholland PJ, Bernhardt ES. 2012. Long-term data reveal patterns and controls on stream water chemistry in a forested stream: Walker Branch, Tennessee. Ecol Monogr 82:367-87.

Marchman SC, Miwa M, Summer WB, Terrell S, Jones DG, Scarbrough SL, Jackson CR. 2013. Clearcutting and pine planting effects on nutrient concentrations and export in two mixed use headwater streams: Upper Coastal Plain, Southeastern USA. Hydrol Process 29:13-28.

Martin CW, Hornbeck JW, Likens GE, Buso DC. 2000. Impacts of intensive harvesting on hydrology and nutrient dynamics of northern hardwood forests. Can J Fish Aquat Sci 57:19-29.

Martin CW, Noel DS, Federer CA. 1984. Effects of forest clearcutting in New England on stream chemistry. J Envron Qual 13:204-10. 
May RM. 1977. Thresholds and breakpoints: ecosystems with a multiplicity of stable states. Nature 269:471-7.

Miniat CF, Brown C, Harper C, Gregory S, Welch B. 2016. Procedures for chemical analysis. Otto, NC: Coweeta Hydrologic Laboratory.

Mitchell MJ, Iwatsubo G, Ohrui K, Nakagawa Y. 1997. Nitrogen saturation in Japanese forests: an evaluation. For Ecol Manag 97:39-51.

Monk CD, Crossley DA, Swank ST, Todd RL, Waide JB, Webster JR. 1977. An overview of nutrient cycling research at Coweeta Hydrologic Laboratory. In: Correll DL, Ed. Watershed research in eastern North America. Smithsonian: Washington, DC. p 505-26.

Mulholland PJ, Hill WR. 1997. Seasonal patterns in streamwater and dissolved organic carbon concentrations: separating catchment flow path and in-stream effects. Water Resour Res 33:1297-306.

Ocampo CJ, Oldham CE, Sivapalan M, Turner JV. 2006. Hydrological versus biogeochemical controls on catchment nitrate export: a test of the flushing mechanism. Hydrol Process 20:4269-86.

Ohte N. 2012. Implications of seasonal variation in nitrate export from forested ecosystems: a review from the hydrological perspective of ecosystem dynamics. Ecol Res 27:657-65.

Ohte N, Mitchell MJ, Shibata H, Tokuchi N, Toda H, Iwatsubo G. 2001. Comparative evaluation on nitrogen saturation of forest catchments in Japan and northeastern United States. Water Air Soil Poll 130:649-54.

Pace ML, Carpenter SR, Cole JJ. 2015. With and without warning: managing ecosystems in a changing world. Front Ecol Environ 13:460-7.

Pace ML, Carpenter SR, Johnson RA, Kurtzweil JT. 2013. Zooplankton provide early warnings of a regime shift in a whole lake manipulation. Limnol Oceanogr 58:525-32.

Patten BC. 2014. Systems ecology and environmentalism: getting the science right. Part I: Facets for a more holistic Nature Book of ecology. Ecol Model 293:4-21.

Perakis SS. 2002. Nutrient limitation, hydrology and watershed nitrogen loss. Hydrol Process 16:3507-11.

Perakis SS, Sinkhorn ER. 2011. Biogeochemistry of a temperate forest nitrogen gradient. Ecology 92:1481-91.

Perakis SS, Tepley AJ, Compton JE. 2015. Disturbance and topography shape nitrogen availability and $\delta^{15} \mathrm{~N}$ over longterm forest succession. Ecosystems 18:573-88.

Peterjohn WT, Adams MB, Gilliam FS. 1996. Symptoms of nitrogen saturation in two central Appalachian hardwood forest ecosystems. Biogeochemistry 35:507-22.

Ranger J, Loyer S, Gelhaye D, Pollier B, Bonnaud P. 2007. Effects of the clear-cutting of a Douglas-fir plantation (Pseudotsuga menziesii $\mathrm{F}$.) on the chemical composition of soil solutions and on the leaching of DOC and ions in drainage waters. Ann For Sci 64:183-200.

Rhoades CC, McCutchan JH, Cooper LA, Clow D, Detmer TM, Briggs JS, Stednick JD, Veblen TT, Ertz RM, Likens GE, Lewis WM. 2013. Biogeochemistry of beetle-killed forests: explaining a weak nitrate response. Proc Natl Acad Sci USA 110:1756-60.

Richter DD, Markewitz D. 2001. Understanding soil change: Soil sustainability over millennia, centuries, and decades. Cambridge: Cambridge University Press.

Riscassi AL, Scanlon TM. 2009. Nitrate variability in hydrological flow paths for three mid-Appalachian forested watersheds following a large-scale defoliation. J Geophys Res 114:G02009.

Roberts BJ, Mulholland PJ. 2007. In-stream biotic control on nutrient biogeochemistry in a forested stream, West Fork of Walker Branch. J Geophys Res 112:G04002.

Roberts BJ, Mulholland PJ, Hill WR. 2007. Multiple scales of temporal variability in ecosystem metabolism rates: results from 2 years of continuous monitoring in a forested headwater stream. Ecosystems 10:588-606.

Robinson CT, Uehlinger U. 2008. Experimental floods cause ecosystem regime shift in a regulated river. Ecol Appl 18:51126.

Runkel RL, Crawford CG, Cohn TA. 2004. Load estimator (LOADEST): A FORTRAN program for estimating constituent loads in streams and rivers. Reston, VA: U.S. Geologic Survey Techniques and Methods Book 4, Chapter A5.

Sabater F, Buturini A, Martí E, Muñoz I, Romaní A, Wray J, Sabater S. 2000. Effects of riparian vegetation removal on nutrient retention in a Mediterranean stream. J N Am Benthol Soc 19:609-20.

Scheffer M, Carpenter S, Foley JA, Folke C, Walker B. 2001. Catastrophic shifts in ecosystems. Nature 413:591-6.

Scheffer M, Rinaldi S, Gragnani A, Mur LR, van Nes EH. 1997. On the dominance of filamentous cyanobacteria in shallow, turbid lakes. Ecology 78:272-82.

Sebestyen SD, Shanley JB, Boyer EW, Kendall C, Doctor DH. 2014. Coupled hydrological and biogeochemical processes controlling variability of nitrogen species in streamflow during autumn in an upland forest. Water Resour Res 50:1569-91.

Sollins P, Grier CC, Fogel R, McCorison FM, Cromack K. 1980. The internal elemental cycles of an old-growth Douglas-fir ecosystem in western Oregon. Ecol Monogr 50:261-85.

Standish RJ, Hobbs RJ, Mayfield MM, Bestelmeyer BT, Suding KN, Battaglia LL, Eviner V, Hawkes CV, Temperton VM, Cramer VA, Harris JA, Funk JL, Thomas PA. 2014. Resilience in ecology: abstraction, distraction, or where the action is? Biol Conserv 177:43-51.

Stoddard JL. 1994. Long-term changes in watershed retention of nitrogen. In: Baker L, Ed. Environmental chemistry of lakes and reservoirs. Washington, DC: American Chemical Society. p 223-84.

Svendsen LM, Kronvang B, Kristensen P, Graesbol P. 1995. Dynamics of phosphorus-compounds in a lowland river system-importance of retention and nonpoint sources. Hydrol Process 9:119-42.

Swank WT. 1986. Biological control of solute losses from forest ecosystems. In: Trudgill ST, Ed. Solute processes. New York: Wiley. p 85-139.

Swank WT, Douglass JE. 1977. Nutrient budgets for undisturbed and manipulated hardwood forest ecosystems in the mountains of North Carolina. In: Correll DL, Ed. Watershed research in eastern North America. Smithsonian Institution: Washington, DC. p 343-62.

Swank WT, Knoepp JD, Vose JM, Laseter SN, Webster JR. 2014. Response and recovery of water yield and timing, stream sediment, abiotic parameters, and stream chemistry following logging. In: Swank WT, Webster JR, Eds. Long-term response of a forest watershed ecosystem. Clearcutting in the southern Appalachians. Oxford: Oxford University Press. p 36-56.

Swank WT, Swift LW, Douglass JE. 1988. Streamflow changes associated with forest cutting, species conversions, and natural disturbances. In: Swank WT, Crossley DA, Eds. Forest 
hydrology and ecology at Coweeta. New York: Springer. p 297-312.

Swank WT, Vose JM. 1997. Long-term nitrogen dynamics of Coweeta forested watersheds in the southeastern United States of America. Glob Biogeochem Cycles 11:657-71.

Swank WT, Waide JB, Crossley DA, Todd RL. 1981. Insect defoliation enhances nitrate export from forest ecosystems. Oecologia 51:297-9.

Swank WT, Webster JR. 2014a. Long-term response of a forest watershed ecosystem: clearcutting in the southern Appalachians. New York: Oxford University Press.

Swank WT, Webster JR. 2014b. Programmatic background, site description, experimental approach and treatment, and natural disturbances. In: Swank WT, Webster JR, Eds. Long-term response of a forest watershed ecosystem. Clearcutting in the southern Appalachians. Oxford: Oxford University Press. p 110.

Swift LW, Cunningham GB, Douglass JE. 1988. Climatology and hydrology. In: Swank WT, Crossley DA, Eds. Forest hydrology and ecology at Coweeta. New York: Springer. p 35-55.

Swift LW, Swank WT. 1981. Long term responses of streamflow following clearcutting and regrowth. Hydrol Sci Bull 26:24556.

Tague CL, Band LE. 2004. RHESSys: regional hydro-ecologic simulation system-an object-oriented approach to spatially distributed modeling of carbon, water, and nutrient cycling. Earth Interact 8:1-42.

Thompson SE, Basu NB, Lascurain J, Aubeneau A, Rao PSC. 2011. Relative dominance of hydrologic versus biogeochemical factors on solute export across impact gradients. Water Resour Res 47:W00J05.

Vaché K, Breuer L, Jones J, Sollins P. 2015. Catchment-scale modeling of nitrogen dynamics in a temperate forested watershed, Oregon. An interdisciplinary communication strategy. Water 7:5345.

Valett HM, Thomas SA, Mulholland PJ, Webster JR, Dahm CN, Fellows CS, Crenshaw CL, Peterson CG. 2008. Endogenous and exogenous control of ecosystem function: $\mathrm{N}$ cycling in headwater streams. Ecology 89:3515-27.

Van Miegroet H, Cole DW. 1985. Acidification sources in red alder and Douglas-fir soils-importance of nitrification. Soil Sci Soc Am J 49:1274-9.

Van Miegroet H, Homann PS, Cole DW. 1992. Soil-nitrogen dynamics following harvesting and conversion of red alder and Douglas-fir stands. Soil Sci Soc Am J 56:1311-18.

Vitousek PM, Melillo JM. 1979. Nitrate losses from disturbed forests: patterns and mechanisms. For Sci 25:605-19.

Vitousek PM, Reiners WA. 1975. Ecosystem succession and nutrient retention: a hypothesis. Bioscience 25:376-81.
Waide JB, Webster JR. 1976. Engineering systems analysis: applicability to ecosystems. In: Patten BC, Ed. Systems analysis and simulation in ecology. New York: Academic Press. p 329-71.

Walling DE, Webb BW. 1986. Solutes in river systems. In: Trudgill ST, Ed. Solute processes. Chichester: Wiley. p 251327.

Webb BW, Walling DE. 1985. Nitrate behavior in streamflow from a grassland catchment in Devon, UK. Water Res 19:1005-16.

Webster JR, Benfield EF, Cecala KK, Chamblee JF, Dehring CA, Gragson T, Cymerman JH, Jackson CR, Knoepp JD, Leigh DS, Maerz JC, Pringle CM. 2012. Water quality and exurbanization in southern Appalachian streams. In: Boon PJ, Raven PJ, Eds. River conservation and management. Chichister: Wiley. p 91-106.

Webster JR, Benfield EF, Golladay SW, McTammany ME. 2014a. Recovery of particulate organic matter dynamics in a stream draining a logged watershed. A pressing situation. In: Swank WT, Webster JR, Eds. Long-term response of a forest watershed ecosystem. Clearcutting in the southern Appalachians. Oxford: Oxford University Press. p 156-76.

Webster JR, Newbold JD, Lin L. 2016. Nutrient spiraling and transport in streams-the importance of instream biological processes to nutrient dynamics in streams. In: Jones J, Stanley E, Eds. Stream ecosystems in a changing environment. Amsterdam: Elsevier.

Webster JR, Newbold JD, Thomas SA, Valett HM, Mulholland PJ. 2009. Nutrient uptake and mineralization during leaf decay in streams-a model simulation. Int Rev Hydrobiol 94:372-90.

Webster JR, Swank WT, Vose JM, Knoepp JD, Elliott KJ. 2014b. Ecosystem stability and forest watershed management: A synthesis of 30+ years of research on WS 7. In: Swank WT, Webster JR, Eds. Long-term response of a forest watershed ecosystem: clearcutting in the southern Appalachians. New York: Oxford University Press. p 229-47.

White DL, Haines BL, Boring LR. 1988. Litter decomposition in southern Appalachian black locust and pine-hardwood stands: litter quality and nitrogen dynamics. Can J For Res 18:54-63.

Woodwell GM. 1975. The threshold problem in ecology. In: Levin SA, Ed. Ecosystem analysis and prediction. Philadelphia: Society for Industrial and Applied Mathematics. p 9-21.

Worrall F, Swank WT, Burt TP. 2003. Changes in stream nitrate concentrations due to land management practices, ecological succession, and climate: developing a systems approach to integrated catchment response. Wat Resour Res 39:1177. 